\title{
Piotr Biliński, Władysław Konopczyński 1880-1952. Człowiek i dzieło, Kraków 2017, ss. 622
}

Władysław Konopczyński (1880-1952) był historykiem okresu wczesnonowożytnego, specjalizującym się w dziejach Rzeczypospolitej Obojga Narodów w XVIII w. Zainicjował Polski Słownik Biograficzny - od 1931 r. do 1949 r. pełnił funkcję redaktora tej wielotomowej publikacji. W latach 1918-1948 pracował jako profesor na Uniwersytecie Jagiellońskim. W 1939 r. został dziekanem Wydziału Filozoficznego UJ. Działał w Polskiej Akademii Umiejętności oraz Polskim Towarzystwie Historycznym, którego został prezesem w 1947 r. Zaangażował się politycznie - w latach 1922-1927 zasiadał w Sejmie, reprezentując Narodową Demokrację.

Praca naukowa i polityczna Konopczyńskiego przypadła na trudne czasy przełomowych wydarzeń historycznych. Opisanie jego losów było zadaniem niełatwym, ponieważ wymagało odwołania się do złożonego kontekstu historycznego okresu zaborów, I wojny światowej, II Rzeczypospolitej, II wojny światowej, a następnie pierwszych lat Polski Ludowej. Być może dlatego - do czasu napisania recenzowanej publikacji - nie została opracowana i wydana jego kompleksowa biografia. Szczególnie trudnym zagadnieniem było przedstawienie szeroko zakrojonej działalności Konopczyńskiego na polu naukowym, którego Zofia Zielińska (profesor na UW) określiła mianem najwybitniejszego polskiego historyka w XX w. Zadania przygotowania biografii tego historyka podjął się Piotr Biliński. Autor od czasu studiów i pracy magisterskiej, opublikowanej w 1999 r. pt. Władysław Konopczyński. Historyk i polityk II Rzeczypospolitej (1880-1952)1 , zbierał kolejne archiwalia i relacje świadków, które znalazły odzwierciedlenie w monografii Władysław Konopczyński 1880-1952. Człowiek i dzieło, opublikowanej w Krakowie w 2017 r.

Piotr Biliński jest profesorem zatrudnionym w Instytucie Studiów Międzykulturowych na Uniwersytecie Jagiellońskim, gdzie pełni funkcję kierownika Zakładu Historii Kulturowej. Specjalizuje się w historii kultury i nauki. W kręgu jego zainteresowań znajduje się problematyka

1 P. Biliński, Władysław Konopczyński. Historyk i polityk II Rzeczypospolitej (1880-1952), Warszawa 1999. 
z zakresu dziejów ziemiaństwa polskiego, historii historiografii, dziejów Kościoła polskiego oraz doktryn politycznych. Piotra Bilińskiego interesują - w szerszym aspekcie - zagadnienia z zakresu historii Polski oraz powszechnej XIX i XX w., ale też epok wcześniejszych.

Szczególnie znajomość realiów okresu wczesnonowożytnego okazała się przydatna przy opracowywaniu recenzowanej biografii - ze względu na twórczość naukową Konopczyńskiego, która dotyczyła tego okresu. Autor nie zdecydował się jednak na przyjęcie szerszej perspektywy - uwzględniającej ocenę dorobku historyka na polu naukowym, co jest konsekwencją uznania, że tym zagadnieniem powinni zająć się badacze specjalizujący się w historii wczesnonowożytnej. Niemniej jednak w recenzowanej pracy ukazany został merytoryczny dorobek Konopczyńskiego, nierozerwalnie wiążący się z jego biografią.

Do prac P. Bilińskiego o charakterze zarówno naukowym, jak i politycznym można zaliczyć jego inną publikację - poświęconą postaci historyka ustroju, profesora Stanisława Kutrzeby². Wcześniejsze analizy Autora dotyczące postaci Konopczyńskiego znalazły odzwierciedlenie nie tylko $\mathrm{w}$ pierwszym zarysie biografii, ale także w formie artykułów oraz opracowanych i wydanych drukiem - we współpracy z Pawłem Plichtą - dwóch części dziennika uczonego (do lat 1918-1921)³. W przyszłości Piotr Biliński planuje publikację kolejnych części dziennika Konopczyńskiego. Warto podkreślić przyjętą przez Autora perspektywę historyczną oraz obiektywizm dokonywanych ocen życia i dzieła Władysława Konopczyńskiego, tak bardzo krzywdzonego przez marksistowskich historiografów, kierujących się racjami politycznymi.

Biografia Władysława Konopczyńskiego składa się z sześciu rozdziałów - są to kolejno: Młodość i początki kariery naukowej (s. 21-121), W polityce II Rzeczypospolitej (s. 123-190), Profesura na Uniwersytecie Jagiellońskim (s. 191-312), Działalność w Polskim Towarzystwie Historycznym (s. 313-421), Działalność w Polskiej Akademii Umiejętności (s. 313-371), Okupacyjne losy (s. 423-457) oraz Dyskryminacja w czasach Polski Ludowej (s. 459-528). Pracę rozpoczyna - liczący 11 stron - Wstęp autorstwa P. Bilińskiego, w którym Autor recenzowanej biografii przedstawia sylwetkę Konopczyńskiego - przede wszystkim jako historyka, a w mniejszym stopniu działacza politycznego. $Z$ perspektywy czasu można jednoznacznie stwierdzić, że po Konopczyńskim pozostały nie doraźne akty polityczne, lecz znaczący

2 Idem, Stanisław Kutrzeba. Człowiek i dzieło (1876-1946). Biografia naukowa i polityczna, Kraków 2011.

3 W. Konopczyński, Dziennik 1918-1921, cz. 1-2, oprac. P. Biliński, P. Plichta, Warszawa-Kraków 2016. 
dorobek naukowy. Zdaniem Władysława Folkierskiego - przywołanego przez Autora we Wstępie - „dobrze wypełnione może być życie poświęcone przeczytaniu tego wszystkiego, co Konopczyński napisal" ${ }^{4}$. Piotr Biliński zaznaczył, że działalność Władysława Konopczyńskiego jako polityka sprowadzała się głównie do mandatu na Sejm RP, gdzie w latach 1922-1927 zasiadał z ramienia narodowodemokratycznego Związku Ludowo-Narodowego. Tezy tej nie sposób podważyć, ale to właśnie z okresem zaangażowania politycznego Konopczyńskiego, a także wyznawanych przez niego poglądów łączą się największe kontrowersje. Za problematyczny uchodził zwłaszcza jego stosunek - zwolennika numerus clausus - do Żydów. Wrogów uczonemu przysparzała również jego negatywna ocena piłsudczyków, a po II wojnie światowej - komunistów. Kontrowersje te kontrastują z opinią o Konopczyńskim jego uczniów, przez których traktowany był ,jjako wielki uczony, zasłużony badacz XVIII wieku, człowiek niezwykle ciepły i życzliwy, otoczony gronem przyjaciół wywodzących się zarówno z równolatków, jak i studentów" (s. 9). Wątki te zostały rozwinięte przez $\mathrm{P}$. Bilińskiego $\mathrm{w}$ ramach poszczególnych części recenzowanej biografii Konopczyńskiego. We Wstępie Autor monografii wprowadził czytelnika w zmienne realia historyczne, w jakich funkcjonował uczony. Dzięki temu można łatwiej zrozumieć doświadczenia Konopczyńskiego i sposób postrzegania przez niego rzeczywistości.

We Wstępie P. Biliński określił cel przygotowania biografii, za który uznał „przedstawienie w sposób analityczny życia i działalności W. Konopczyńskiego w oparciu o nieznane dotychczas źródła, szczególnie prywatne archiwum rodziny Konopczyńskich, będące w posiadaniu najmłodszej córki historyka, Wandy Mrozowskiej" (s. 10). Innym celem była chęć rozwikłania "zagadek, niedomówień i przekłaman" (s. 10) związanych z postacią uczonego. Brak omówienia niektórych zagadnień Autor wyjaśnił występującymi lukami źródłowymi. Mimo to zamieszczony na końcu pracy (s. 533-587) wykaz źródeł i opracowań jest imponujący. Piotr Biliński wyzyskał źródła z blisko 30 placówek - zarówno krajowych, jak i zagranicznych archiwów oraz bibliotek. Bibliografię recenzowanej publikacji tworzy imponujący zbiór drukowanych i niedrukowanych prac Konopczyńskiego, a także liczne źródła drukowane oraz literatura przedmiotu. Ilość wykorzystanego materiału źródłowego i opracowań świadczy o kompleksowym przygotowaniu Autora do podjęcia zadania napisania biografii Władysława Konopczyńskiego.

4 W. Folkierski, Tytan historycznej pracy. Władysław Konopczyński, "Myśl Polska” 15 VIII 1952. Cyt. za: P. Biliński, Władysław Konopczyński 1880-1952. Człowiek i dzieło, Kraków 2017, s. 9. 
Rozdział pierwszy rozpoczyna się od omówienia lat szkolnych i uniwersyteckich Konopczyńskiego, który urodził się 26 listopada 1880 r. w Warszawie. Przedstawione zostały najważniejsze informacje z życia rodziców bohatera biografii - Ignacego Wojciecha i Ludwiki Anastazji z Obrąpalskich. Piotr Biliński umiejętnie wskazał na znaczenie poszczególnych postaci w rozwoju osobowości uczonego oraz jego tożsamości naukowej. Bez tego bowiem nie byłaby możliwa dalsza kompleksowa analiza. Przedstawiony został wpływ, jaki na rozwój intelektualny bohatera recenzowanej monografii miał jego stryj - Emilian Konopczyński, który był cenionym warszawskim pedagogiem. To on zaszczepił młodemu Władysławowi zainteresowanie humanistyka, które następnie rozwinęło się pod wpływem inspiratora „optymistycznej” warszawskiej szkoły historycznej - Tadeusza Korzona. Znajomość z Korzonem kilkunastoletni Władysław zawdzięczał dziadkowi - Erazmowi Obrąpalskiemu. Razem z nim brał udział w organizowanych przez Korzona środowych spotkaniach intelektualistów, którzy dyskutowali nad rozmaitymi zagadnieniami z zakresu historii, literatury, kultury, a także problemów społecznych i politycznych. Bohater recenzowanej pracy wspominał rozmowy z Korzonem jako „pierwsze, najowocniejsze seminarium" (s. 30). W rezultacie Konopczyński w młodości ukształtował się w opozycji do „pesymistycznej” krakowskiej szkoły historycznej, a w szczególności - koncepcji upadku Rzeczypospolitej Obojga Narodów, którą prezentował Michał Bobrzyński. Przedstawienie przez P. Bilińskiego wpływu intelektualnych młodzieńczych inspiracji Konopczyńskiego miało znaczenie ze względu na jego późniejsze zainteresowania okresem I Rzeczypospolitej, w której dziejach wyspecjalizował się jako historyk. Po okresie studiów na Wydziale Prawa Carskiego Uniwersytetu Warszawskiego nie związał się na trwałe z tą uczelnią, na co wpływ miała jego znajomość ze znanym lwowskim historykiem, Szymonem Askenazym.

Podjęcie pracy naukowej pod kierunkiem Askenazego oznaczało związanie się przez Konopczyńskiego z Uniwersytetem Lwowskim. Piotr Biliński omówił złożony stosunek Konopczyńskiego do Askenazego, który z czasem przybierał znamiona obustronnej niechęci, a w konsekwencji narastających - na różnych polach - rozbieżności między historykami. Podjęcie przez Autora rzetelnej analizy tego zagadnienia ułatwiły jego wcześniejsze badania, które w 2014 r. znalazły odzwierciedlenie w artykule opisującym spór Konopczyńskiego z Askenazym5

5 P. Biliński, Spór Władysława Konopczyńskiego z Szymonem Askenazym, w: Władysław Konopczyński jako badacz dziejów XVIII wieku, red. Z. Zielińska, W. Kriegseisen, Warszawa 2014, s. 191-2017; idem, Lwowskie lata Władysława Konopczyńskiego, „Wrocławskie Studia Wschodnie" 2014, 18, s. 91-102. 
Pod opieką Askenazego Konopczyński obronił doktorat w listopadzie 1908 r. - na podstawie pierwszego tomu pracy Polska $w$ dobie wojny siedmioletniej - lecz okazało się, że w konsekwencji sporu z promotorem nie miał szans na profesurę na Uniwersytecie Lwowskim. Zaletą omówienia przez Piotra Bilińskiego tej kwestii jest ukazanie animozji występujących w środowisku akademickim na szerszej płaszczyźnie - nieograniczającej się jedynie do wzajemnej niechęci Konopczyńskiego i Askenazego. Świadectwem tego zjawiska było szybsze zaakceptowanie Konopczyńskiego na Uniwersytecie Jagiellońskim przez grono historyków niechętnych Askenazemu. To właśnie w Krakowie - w kwietniu 1911 r. - Konopczyński uzyskał habilitację na podstawie tomu drugiego pracy Polska w dobie wojny siedmioletniej. Przypieczętowaniem związków Konopczyńskiego z Krakowem było objęcie przez niego katedry historii Polski na Uniwersytecie Jagiellońskim po zmarłym w 1917 r. profesorze Stanisławie Krzyżanowskim. Był to przełom w jego życiu, ponieważ umożliwiał mu stabilizację. Kolejnym przełomem było nadanie Konopczyńskiemu - 18 czerwca 1920 r. - profesury zwyczajnej przez Radę Wydziału Filozoficznego UJ. Wydarzenie to, już z okresu II RP, Piotr Biliński zdecydował się omówić na zakończenie pierwszego rozdziału. Zdaniem Autora recenzowanej pracy koniec „pierwszej wojny światowej kończy w życiu Władysława Konopczyńskiego okres formowania się jego warsztatu badawczego i ugruntowania pozycji zawodowej" (s. 120).

W rozdziale drugim P. Biliński przedstawił postać Władysława Konopczyńskiego jako polityka. W pierwszej kolejności omówił okres jego pracy poselskiej w Sejmie w latach 1922-1927, z którym związane są największe kontrowersje. W tym czasie jako poseł podejmował rozmaite obowiązki, a mimo to jest postrzegany przede wszystkim przez pryzmat pełnienia funkcji referenta wniosku o numerus clausus, porządkującego kwestię mniejszości narodowych. Lewicowa opozycja przypisywała Konopczyńskiemu złe intencje, a nawet nacjonalizm. W rzeczywistości uczony szukał sprawiedliwego rozwiązania problemu partycypacji w studiach osób innego wyznania niż katolickie. Działając od października 1918 r. w Stronnictwie Demokratyczno-Narodowym, identyfikował się z linią tego obozu politycznego. Szczególną inspiracją były dla niego - jeszcze w okresie poprzedzającym wybuch I wojny światowej - poglądy Romana Dmowskiego. Piotr Biliński odrzucił jednostronną interpretację ideologiczną - opowiedział się za analizą merytoryczną. Odrzucił tezę, iż Konopczyński był partyjnym doktrynerem, wskazując przy tym, że bohater biografii promował i wspierał doktorantów pochodzenia żydowskiego - w szczególności Józefa Feldmana, ale także Waltera Tauba czy Franciszkę Freundlichową. Autor zwraca też uwagę, że Konopczyński potępiał zabójstwo Prezyden- 
ta RP, Gabriela Narutowicza przez fanatycznego zwolennika Narodowej Demokracji - Eligiusza Niewiadomskiego. Uczony całkowicie odrzucał koncepcję numerus nullus.

Nowy etap w życiu Władysława Konopczyńskiego wiązał się z dojściem do władzy obozu piłsudczykowskiego w maju 1926 r. Zasadne jest więc wydzielenie z rozdziału drugiego fragmentu poświęconego jego działalności politycznej od przewrotu majowego. Nieprzypadkowo podrozdział ten zatytułowano Walka z sanacja, ponieważ bohater recenzowanej pracy był przeciwnikiem Józefa Piłsudskiego i jego współpracowników. Przedstawienie konfliktu Konopczyńskiego z piłsudczykami P. Biliński rozpoczął od prezentacji stanowiska bohatera recenzowanej pracy wobec zarzutów Piłsudskiego o fałszowanie dokumentów dotyczących wojny polsko-bolszewickiej. Zarzuty te zostały skierowane przez Komendanta w 1925 r. pod adresem generałów Władysława Sikorskiego oraz Stanisława Hallera. W rezultacie Sikorski, będący ówcześnie ministrem spraw wojskowych, doprowadził do powołania Konopczyńskiego jako jednego z członków specjalnej komisji, mającej na celu ustalenie, czy zarzuty Piłsudskiego są zasadne. P. Biliński ukazał negatywny stosunek Konopczyńskiego wobec Piłsudskiego, który - abstrahując od oceny zasadności zarzutów stawianych przez Komendanta - wpisywał się w popularny trend Narodowej Demokracji, wyrażający się $\mathrm{w}$ dyskredytowaniu roli Piłsudskiego w wojnie z bolszewicką Rosją. Autor biografii nie zwrócił uwagi, że wielu współczesnych historyków nie umniejsza korzystnego wpływu koncepcji Piłsudskiego, który w wojnie z bolszewikami był Naczelnym Wodzem. Intencją P. Bilińskiego było przedstawienie Konopczyńskiego jako historyka dążącego do poznania prawdy, co przedkładał ponad mit Komendanta. Wydaje się jednak, że ten kierunek rozważań warto byłoby uzupełnić spostrzeżeniem o „totalnej" krytyce Piłsudskiego, której autorem był Konopczyński.

Zastanawiające jest, czy Konopczyński, walcząc z mitem Piłsudskiego, nie zatracił zdolności do bezstronnego spojrzenia. Piotr Biliński dostrzegł, że w publicystyce uczonego Piłsudski był przedstawiany jako „źródło wszelkiego zła, uosobienie buntownictwa, ośrodek deprawacji politycznej" (s. 168). Mimo to Autor biografii skupił się przede wszystkim na niechęci, jakiej doświadczył Konopczyński od zwolenników Piłsudskiego. Świadectwem tego była też niechęć ze strony Stanisława Estreichera. Obaj nie podawali sobie ręki do czasu, aż znaleźli się w obozie koncentracyjnym Sachsenhausen. Warto się zastanowić, czy analogie między okresem I i II RP (w zamierzeniu dyskredytujące piłsudczyków), które często przedstawiał w publicystyce Konopczyński nie szły zbyt daleko. Ukazując rolę Konopczyńskiego w Narodowej Demokracji, Piotr Biliński wykazał się znajomością realiów politycznych w Polsce - zarówno w latach 1918-1926, jak i 1926-1939. 
Rozdział trzeci Autor biografii rozpoczął od opisania polemiki Władysława Konopczyńskiego z innym historykiem - Mieczysławem Skibińskim ${ }^{6}$. Zwrócił przy tym uwagę, że Skibiński był uczniem Szymona Askenazego, jednak podłoże konfliktu opisał jako bardziej złożone. Bohater biografii negatywnie oceniał starania Skibińskiego o habilitację. Czynił to konsekwentnie, będąc przekonanym o niespełnianiu przez ucznia Askenazego wymogów warsztatu naukowego, a nie z pobudek osobistych. W rezultacie uniemożliwił Skibińskiemu akademicką karierę naukową. Władysław Konopczyński w formie recenzji bądź polemik prasowych spierał się także z innymi historykami - Autor jego biografii opisał takie zmagania z Antonim Chołoniewskim oraz Władysławem Semkowiczem. W tym samym rozdziale Piotr Biliński opisał polemikę Konopczyńskiego ze współtwórcą krakowskiej szkoły historycznej - Michałem Bobrzyńskim. Mogłoby się wydawać, że Konopczyńskiemu - ze względu na znajomość z Korzonem - była zdecydowanie bliższa „optymistyczna” szkoła. Mimo zauważalnego krytycyzmu wobec tez Bobrzyńskiego, Autor biografii Konopczyńskiego dostrzegł złożony stosunek do przyczyn upadku I Rzeczypospolitej. Władysław Konopczyński poszukiwał równowagi. Rozumiał negatywne dla Rzeczypospolitej Obojga Narodów konsekwencje zaborczej polityki sąsiadów, w szczególności wskazując na rolę Prus Hohenzollernów. Z drugiej jednak strony odwoływał się do znaczenia mankamentów ustrojowych I RP, czego znamiennym świadectwem była jego praca Liberum veto. Studium historyczno-porózwnawcze ${ }^{7}$.

W rozdziale trzecim Piotr Biliński zanalizował relacje występujące między Konopczyńskim a jego uczniami. Zwrócił uwagę na sposób przygotowywania przez uczonego wykładów oraz organizacji seminarium doktoranckiego. Dorobek Konopczyńskiego jako promotora przedstawił w sposób trafny - urozmaicając przekaz obrazującymi osobowość historyka cytatami jego uczniów. Zwłaszcza przywołane przez Autora wspomnienia Adama Przybosia pozwalają na przyjęcie założenia, że Konopczyński był typem profesora, który nie spóźniał się na zajęcia, miał doskonałą pamięć (także do nazwisk uczniów), a proponując tematy prac, przekazywał tylko najważniejsze informacje. Od uczniów oczekiwał samodzielności prowadzącej do dojrzałości naukowej. Na tym tle zwracają uwagę wnioski Bilińskiego o stylu pracy Konopczyńskiego: „Od każdego seminarzysty wymagał szerokiej kwerendy źródłowej, nie bardzo

6 Zagadnieniem tym Piotr Biliński zajmował się już wcześniej - zob. P. Biliński, Polemika Władysława Konopczyńskiego z Mieczysławem Skibińskim, „Studia z Historii Społeczno-Gospodarczej XIX i XX wieku" 2015, 14, s. 83-91.

7 W. Konopczyński, Liberum veto. Studyum porównawczo-historyczne, Kraków 1918. 
się licząc przy dawaniu tematów z możliwościami uczniów i terminami ukończenia prac magisterskich. Mierzył uczniów według własnych osiągnięć, dlatego też miał ich w większości wybitnych" (s. 221). To podejście przyniosło efekty w postaci wypromowania 46 doktorów, z których część rozwinęła w kolejnych latach naukowe kariery. Przedstawiając uczonego przez pryzmat opinii jego uczniów, Piotr Biliński wykazał, że profesor nie kierował się $\mathrm{w}$ nauce pobudkami ideologicznymi czy wyznaniowymi. Wśród jego seminarzystów znajdowali się zarówno Żydzi, jak i Rusini (Ukraińcy). Zamieszczenie opinii uczniów pozwala czytelnikowi na poznanie rozmaitych anegdot związanych z osobą promotora - dotyczących nie tylko jego zalet, ale i osobliwości. Dowodzą tego zamieszczone w biografii Konopczyńskiego słowa Władysława Czaplińskiego, który dostrzegał u promotora „więcej niż skromne ubranie, kołnierzyk z celulozy, jako tańszy i niewymagający prania”. W. Czapliński wspominał: „Z mieszaniną podziwu i dezaprobaty obserwowaliśmy jego podróże na rowerze z domu przy Sobieskiego na Uniwersytet, niejednokrotnie w meloniku na głowie, fakt ciągnięcia roweru aż na drugie piętro, prawdopodobnie po to, by nie zostawić go na dole w portierni, gdzie trzeba było coś zapłacić portierowi" (s. 250). Zaletą tej części pracy jest zamieszczenie przez P. Bilińskiego dwóch wykazów. Jeden przedstawia wykłady Konopczyńskiego w latach 1912-1948 i zawiera informacje o roku akademickim danego wykładu oraz o jego temacie. W drugim z kolei wykazie Autor umieścił spis rozpraw doktorskich powstałych pod kierunkiem uczonego, uwzględniający imiona i nazwiska autorów, tytuły ich prac oraz daty promocji.

Rozdział trzeci stanowi także analizę dorobku Władysława Konopczyńskiego. Piotr Biliński podkreślił rozległość jego spuścizny naukowej - przedstawiając jako najważniejsze dzieło dwutomową Konfederację barska, którą wydrukowano w latach 1936-1938. W sposób czytelny Autor przedstawił trudności, z jakimi zmagał się profesor, przygotowując poszczególne prace, zwracając przy tym uwagę na sposób ich oceny w środowisku naukowym. Ukazał także stosunek Konopczyńskiego do własnej twórczości. Interesujący jest sposób postrzegania przez uczonego roli historyka, do czego odwołał się P. Biliński, przedstawiając cytat zamieszczony w pracy Józef Szujski 1835-1883, w której Konopczyński uznał, że „łudzi się ten, kto żąda za Leopoldem von Ranke, aby historyk gasił w sobie swoje ja. Można i trzeba, opowiadając dzieje, usuwać w cień swoją osobę, sprawdzać swoje wyniki według zdobyczy współtowarzyszów, ale ostatecznie, jak słusznie sprostował [Georg] Simmel, jedynym narzędziem do poznania innych osobowości, jednym aparatem

8 Idem, Konfederacja barska, t. 1-2, Warszawa 1936-1938. 
transmisyjnym między badaną przyszłością i poznającą teraźniejszością jest osobowość badacza, której część stanowi intelekt, a której nie zastąpi największa erudycja" (s. 264) ${ }^{9}$.

Na zakończenie rozdziału trzeciego P. Biliński odwołał się do - zachowanego maszynopisu - wspomnienia W. Konopczyńskiego. Wspomnienie to - "Smutna historia. O niedoszłym przed wojną wydawnictwie dziejów Polski zbiorowo opracowanych" - dotyczy nieudanych prób uczonego, mających na celu założenie zespołu badawczego, który byłby zdolny do stworzenia pracy poświęconej polskiej historii w różnych epokach. Jako przyczynę niepowodzenia Konopczyńskiego P. Biliński wskazał podejście innych uczonych. Już na pierwszym etapie prac konflikty uniemożliwiły udział w przedsięwzięciu Stanisława Kutrzeby. Kiedy wydawało się, że Konopczyński stworzył odpowiedni zespół badawczy, pojawiła się inna trudność - brak oczekiwanych postępów prac poszczególnych autorów. Niepowodzenia $\mathrm{z}$ tym związane trwały latami $-\mathrm{w}$ rezultacie do wybuchu II wojny światowej nie powstała zbiorowa analiza historii Polski. Bohater biografii konsekwentnie zmierzał jednak do realizacji idei zbiorowych dziejów Polski. W korespondencji z Władysławem Semkowiczem podkreślał nawet, że ideę tę traktuje jako ważniejszą od Polskiego Słownika Biograficznego, którego był twórcą i spiritus movens. Piotr Biliński zwrócił uwagę, że rzeczywistą przyczyną niepowodzenia nie były oficjalne tłumaczenia uczonych, które sprowadzały się do usprawiedliwiania $\mathrm{w}$ postaci powoływania na zajęcia dydaktyczne bądź pracę naukową. Za faktyczną przyczynę uznał brak docenienia inicjatywy Konopczyńskiego oraz niewystarczającą wiarę w realizację przez niego tej idei. Mimo to - jak zauważył P. Biliński - w 1936 r. uczonemu udało się opublikować historię Polski w okresie wczesnonowożytnym, której treść miała stanowić element niedoszłej pracy zbiorowej ${ }^{10}$.

Analiza dotycząca działalności bohatera recenzowanej pracy w Polskim Towarzystwie Historycznym została podjęta w rozdziale czwartym. Już od 1907 r. Konopczyński należał do lwowskiego Towarzystwa Historycznego, a w kolejnych latach był jednym z głównych inspiratorów utworzenia Koła Towarzystwa Historycznego w Krakowie. Działania w tym zakresie zakończyły się powodzeniem w 1913 r. W okresie II RP zaistniały szersze możliwości działalności Towarzystwa, ale także i nowe wyzwania. Piotr Biliński zwrócił uwagę na zabiegi Konopczyńskiego, które wynikały z obaw o zdominowanie krakowskiego ośrodka historycznego przez ośrodek naukowy w Warszawie, w którym prym wiódł Marceli Handelsman. Władysław Konopczyński został przedstawiony jako zwo-

9 Por. idem, Józef Szujski 1835-1883, Warszawa 1993, s. 7-8.

10 Zob. idem, Dzieje Polski nowożytnej, t. 1-2, Warszawa 1936. 
lennik „decentralizacji kultury”, czemu dał wyraz w jednym z listów do Franciszka Bujaka. Analiza P. Bilińskiego, dotycząca prac Konopczyńskiego w Towarzystwie, pozwala na dogłębne poznanie ruchu naukowego w Polsce i jego organizacji - zarówno w okresie pierwszych lat niepodległości, jak i wydarzeń po reorganizacji w 1925 r., która doprowadziła do utworzenia Polskiego Towarzystwa Historycznego.

W 1925 r. Konopczyński został wiceprezesem krakowskiego Oddziału PTH oraz członkiem Zarządu Głównego. Piotr Biliński umiejętnie przedstawił liczne dokonania organizacyjne profesora oraz jego aktywność naukową w PTH. Rozdział ten obrazuje także konflikty między uczonymi, które miały charakter zarówno personalny, jak i dotyczący poglądów politycznych. Świadectwem konfliktów personalnych były opisane i przedstawione z perspektywy Konopczyńskiego zmiany na stanowisku prezesa PTH. W ich konsekwencji w 1932 r. ustąpił prezes Stanisław Zakrzewski, a na jego miejsce powołano Franciszka Bujaka. Po dwóch latach Bujak także ustąpił, natomiast prezesem ponownie został Zakrzewski. W 1936 r., po śmierci Zakrzewskiego, funkcję prezesa po raz kolejny objął Bujak. W kolejnym jednak roku prezesem był już Ludwik Kolankowski. Zmiany na tym stanowisku to tylko jeden przykład opisanych przez P. Bilińskiego kulis działań PTH. Innym elementem był spór między Zarządem Głównym PTH a warszawskim Towarzystwem Miłośników Historii. Konflikt dotyczący polityki pojawił się w 1928 r. Wówczas Konopczyński był przeciwny inicjatywie władz PTH, zmierzającej do nadania Józefowi Piłsudskiego honorowego członkostwa. Nie był jednak w stanie temu zapobiec.

Srodowiskowa niechęć do piłsudczyków stała się przyczyną ich dążeń do ograniczenia autonomii akademickiej w latach trzydziestych. Jeszcze przed okresem reform Janusza Jędrzejewicza środowisko krakowskie sprzeciwiało się aktywnie uwięzieniu polityków opozycji w twierdzy wojskowej w Brześciu. Z tego powodu, kiedy w 1930 r. prezydent Ignacy Mościcki i premier Józef Piłsudski zostali zaproszeni do wzięcia udziału w V Powszechnym Zjeździe Historyków Polskich, Władysław Konopczyński - na znak protestu - zrezygnował z udziału w obradach.

Przedstawiona przez Piotra Bilińskiego - $\mathrm{w}$ rozdziale piątym - działalność Władysława Konopczyńskiego w Polskiej Akademii Umiejętności dotyczy zaangażowania bohatera biografii w prace Komisji Historycznej PAU oraz inicjowania i rozwijania przez niego Polskiego Stownika Biograficznego. W latach 1917-1921 Konopczyński był sekretarzem Komisji Historycznej PAU, w której, jak wykazał P. Biliński, zasługą uczonego było opracowanie katalogu rękopisów oraz przygotowanie biblioteki podręcznej. Autor biografii wskazał też na zakończone niepowodzeniem dążenia Konopczyńskiego do powołania - w ramach Komisji - Instytutu Historycznego, który 
pełniłby rolę centralnego ośrodka dokumentacyjno-informacyjnego. Najwięcej miejsca w analizie podjętej w rozdziale piątym Autor przeznaczył na opisanie spraw dotyczących PSB. Jest to zasadne ze względu na czas, jaki Władysław Konopczyński poświęcił na projektowanie idei, a następnie na realizację koncepcji Polskiego Słownika Biograficznego, który współcześnie jest - jak stwierdza Piotr Biliński - „dumą Krakowa i najcenniejszym wydawnictwem biograficznym kraju, do którego muszą sięgać wszyscy badacze zajmujący się dziejami Polski" (s. 421).

Władysław Konopczyński został redaktorem PSB, którego druk rozpoczął się u schyłku 1934 r. Piotr Biliński zwrócił uwagę, że uczony - mimo głosów przeciwnych w środowisku naukowym - zmierzał do tego, by słownik obejmował całą Polskę historyczna, a nie jedynie okres porozbiorowy. Nie było mu łatwo uzyskać poparcia dla idei PSB ze strony innych uczonych, co stanowiło szczególny mankament ze względu na konieczność organizacji kompetentnego komitetu redakcyjnego. Efektem tych zabiegów było pozyskanie PAU jako wydawcy. Największą trudnością z którą zmagał się Konopczyński były sprawy finansowe. Pozyskanie wsparcia finansowego nie było łatwe - zwłaszcza że brak przychylności okazało lwowskie środowisko historyczne oraz Handelsman z Warszawy. Na przekór trudnościom inicjatywę PSB poparła Kasa Mianowskiego oraz dyrektor Funduszu Kultury Narodowej - Stanisław Michalski. Przychylność dyrektora Michalskiego w stosunku do Konopczyńskiego objawiła się w postaci obietnicy przekazania ze środków Funduszu subwencji na PSB. W 1932 r. oraz w 1934 r. Konopczyński uskarżał się jednak w dzienniku, że nie otrzymał obiecanych przez Michalskiego środków z Funduszu. Piotr Biliński zacytował nawet konstatację Konopczyńskiego: „Na Fundusz Kultury Narodowej coraz mniej liczę. À propos: kto to i kiedy wynalazł powiedzenie: nabierać kogoś na fundusz?" (s. 413). Zasadne byłoby dodanie przez Autora biografii, że Konopczyński nie uwzględnił trudnej sytuacji finansowej Funduszu, który w konsekwencji skutków światowego kryzysu gospodarczego znacząco ograniczył działalność na wielu polach.

Rozdziały szósty i siódmy prezentują funkcjonowanie Władysława Konopczyńskiego w totalitarnych - narodowosocjalistycznych, a następnie komunistycznych - realiach. Po zajęciu Krakowa przez Niemcy uczony nie zaniechał pracy naukowej. W dalszym ciagu był też gotowy do wypełniania obowiązków dziekana Wydziału Filozoficznego UJ. Wraz z innymi profesorami tej uczelni został aresztowany w wyniku niemieckiej Sonderaktion Krakau, do której doszło 6 listopada 1939 r. Z biografii Konopczyńskiego autorstwa P. Bilińskiego, poznajemy dalsze jego losy w więzieniu we Wrocławiu, a następnie w obozie Sachsenhausen. Zwraca uwagę nieludzkie traktowanie profesorów przez niemieckich strażników, stosujących prze- 
moc wobec osadzonych. Informacje o tych realiach obozowych P. Biliński pozyskał z dziennika Konopczyńskiego, będącego cennym źródłem wiedzy nie tylko do okresu poprzedzającego wybuch II wojny światowej, ale także kolejnych lat. Piotrowi Bilińskiemu bohater recenzowanej biografii jawi się jako postać o silnym charakterze, której nie załamały doświadczenia z obozu Sachsenhausen. Tezę tę potwierdzają wydarzenia po zwolnieniu Władysława Konopczyńskiego z obozu w lutym 1940 r. Historyk zaangażował się wówczas w tajne nauczanie na UJ, obejmując w 1942 r. kierownictwo nad studiami historycznymi. Kontynuował nie tylko prace dydaktyczne, ale i naukowe - odbywając kwerendy w Bibliotece Jagiellońskiej, Bibliotece Czartoryskich oraz Archiwum Akt Dawnych. Autor zwrócił uwagę, że przedmiotem badań profesora nie były już tylko zagadnienia z zakresu XVIII stulecia, ale poszerzył je o okres II RP oraz stosunki polsko-niemieckie. Przygotowywał nawet dzieło Piłsudski a Polska. Analiza podjęta w rozdziale poświęconym okupacji niemieckiej, oprócz działalności naukowej uczonego, obejmuje także jego życie rodzinne.

Ostatnie lata życia bohatera recenzowanej pracy zostały ukazane już w realiach Polski Ludowej. Rozdział ten zatytułowano Dyskryminacja w czasach Polski Ludowej, bowiem Władysław Konopczyński był zwalczany przez władze komunistyczne, co Piotr Biliński przedstawił w sposób kompleksowy. Metody tego zwalczania wpisywały się w model dyskryminacji także innych uczonych akademickich. Zdaniem Autora recenzowanej biografii losy „późniejszego prześladowania [Konopczyńskiego] odsłaniają metody działania nowych władz w pierwszych latach istnienia Polski Ludowej i rzucają światło na zakres zniewolenia uczonych, do których dążyli ówcześni polityczni decydenci" (s. 459). W rozdziale tym przedstawiony został dorobek naukowy Konopczyńskiego oraz współpraca z zakonspirowanym Stronnictwem Narodowym. Mimo że był inwigilowany przez władze komunistyczne, nie został aresztowany. W lutym $1945 \mathrm{r}$. wybrano go na przewodniczącego Komisji Historycznej PAU, w czerwcu 1946 r. na prezesa krakowskiego Oddziału PTH, natomiast w kwietniu 1947 r. na prezesa PTH. Piotr Biliński przedstawił te awanse jako kontrastujące z rzeczywistym osłabieniem pozycji Konopczyńskiego w świecie nauki od wiosny 1947 r. Tezę tę miały uzasadniać posądzenia uczonego o „zoologiczny antysemityzm”, które stanowiły pretekst dla ministra oświaty - Stanisława Skrzeszewskiego - do podjęcia represji zmierzających do usunięcia Konopczyńskiego z PTH, UJ i PAU. P. Biliński opisał prześladowania uczonego, który w 1947 r. został pozbawiony funkcji prezesa PTH, a w roku kolejnym - przeniesiony w stan spoczynku przez wiceminister oświaty Eugenię Krassowską. Władysława Konopczyńskiego zwolniono też z funkcji redaktora PSB. Część środowiska uczonych odsunęła się od bohatera recenzowanej publikacji, który pozo- 
stawał krytyczny wobec marksistowskich trendów w nauce. Należy zaznaczyć, że równolegle z prowadzoną przez władze dyskryminacją pogarszał się stan zdrowia uczonego. Władysław Konopczyński zmarł w wyniku zawału serca w Młyniku - w nocy z 12 na 13 lipca 1952 r.

Po rozdziale siódmym P. Biliński zamieścił liczące kilka stron Zakończenie (s. 529-532), w którym dokonał syntetycznej charakterystyki profesora, starając się odpowiedzieć na pytanie, jakim był człowiekiem. Zdaniem Autora: „Konopczyński jako historyk, polityk i mąż stanu był osobowością wielkiego formatu, wyrastająca ponad przeciętność czasów, w których przyszło mu żyć i działać" (s. 530). W Zakończeniu zostały także przedstawione dalsze losy - po śmierci uczonego - rodziny Konopczyńskich oraz dworku w Młyniku. Po obszernej bibliografii Autor zamieścił wykaz skrótów (s. 588-589), abstrakt w języku angielskim (s. 590-597) oraz indeks osobowy (s. 598-622). Dodatkiem podnoszącym wartość dzieła jest 25 fotografii, pochodzących z prywatnych zbiorów rodziny Konopczyńskich w Gliwicach. Fotografie te przedstawiają zarówno uczonego (w różnych okresach jego życia), jak i jego najbliższych. Na końcu umieszczono tablicę genealogiczną Władysława Konopczyńskiego i Jadwigi z Lutostańskich.

Autor recenzowanej pracy zdecydował się umieścić w tytule określenie "Człowiek i dzieło", co sugeruje, że postrzegał Władysława Konopczyńskiego przede wszystkim przez pryzmat jego działalności naukowej, w której odnosił największe sukcesy. Zauważalne jest jednak, że nauka i polityka w życiu uczonego często się przeplatały. Można nawet mówić o wpływie wydarzeń politycznych na jego twórczość naukową. Zagadnienie stosunków polsko-szwedzkich w XVII i XVIII w. Konopczyński podjął w rezultacie pobytu w Szwecji, który był wymuszony wybuchem I wojny światowej, bowiem przebywając wówczas w Gdyni - jako obywatel rosyjski - został zmuszony do przeniesienia się na teren Skandynawii. Będąc półtora roku w Szwecji z rodziną, uczył się języków skandynawskich. Odbywał też kwerendy archiwalne w Szwecji i w Danii. Tego typu powiązań nauki i polityki w życiu Władysława Konopczyńskiego było więcej. Jednym z nich był okres działalności w ramach Biura Prac Kongresowych i związany z tym pobyt na paryskiej konferencji pokojowej. Przy tej okazji uczony odbywał też kwerendy - m.in. w Bibliotece Polskiej w Paryżu.

Piotr Biliński zastrzegł we Wstępie, że praca ma układ chronologiczny, a jedynie w niektórych przypadkach problemowy. Zastosowanie formy chronologiczno-problemowej jest zauważalne nie tylko w zestawieniu poszczególnych rozdziałów, ale nawet w treści wielu podrozdziałów. Przykładem tego jest informacja o znalezieniu się w księgarniach pracy Konopczyńskiego o stosunkach Polski i Szwecji w okresie wczesnonowożytnym, która poprzedza opis jego drogi do objęcia katedry historii Polski na UJ 
- po zmarłym w 1917 r. profesorze Stanisławie Krzyżanowskim. Charakter chronologiczno-problemowy być może wynika z opublikowania przez P. Bilińskiego niektórych części pracy w ramach wcześniejszych artykułów. Z drugiej strony wyczerpanie pewnych zagadnień - bez ponownego do nich powracania - obligowało do omawiania poszczególnych problemów, nawet mimo odchodzenia od chronologii. Nie powinno to sprawiać problemów czytelnikom, ponieważ Autor w sposób wyczerpujący i uporządkowany omówił poszczególne zagadnienia.

W wielu kwestiach Piotr Biliński był uzależniony od dziennika Władysława Konopczyńskiego, stanowiącego podstawowe źródło przygotowywanej pracy. Wymagało to gruntowanej znajomości treści zapisek uczonego oraz krytycznego ustosunkowania się do nich. Wywiązanie się $\mathrm{z}$ tego zadania umożliwiły Autorowi wieloletnie badania prowadzone nad dziennikiem Konopczyńskiego, które pozwoliły na dobranie do biografii treści zapisek najlepiej charakteryzujących osobowość uczonego. Zwraca uwagę przedstawiona przez P. Bilińskiego zarówno bezkompromisowość, jak i ostrość sądów bohatera biografii. Jako dowód mogą tu posłużyć wyrażane przez profesora opinie o Szymonie Askenazym („wykładał ładnie, tylko bez należytego przygotowania i z trudnością myśli zbierał" [s. 57]), Ludwiku Kolankowskim (nie ma „większego łgarza między historykami” [s. 117]), lwowskich historykach (wielu z nich "traktuje swą rzecz [obowiązki] per nogam" [s. 55]) czy prezydencie Ignacym Mościckim, którego określił mianem „politycznego analfabety” (s. 166).

Biografia Władysława Konopczyńskiego to obowiązkowa lektura dla badaczy zajmujących się nauką i polityką w Polsce w pierwszej połowie XX w. Wynika to z pozycji uczonego w świecie nauki oraz kontaktów z tym środowiskiem, a także cennych obserwacji jego autorstwa. Biografia Konopczyńskiego jest godna polecenia nie tylko wąskiemu gronu specjalistów, ale także pasjonatom historii. Postać profesora nie została przedstawiona w oderwaniu od tła historycznego, co pozwala na pełniejsze zrozumienie złożonych losów uczonego. Język pracy jest przystępny, a obecne w książce przypisy pozwalają na dotarcie do materiałów źródłowych oraz opracowań naukowych - ułatwiających rozwinięcie poszczególnych wątków. Zaletę stanowi też to, że Piotr Biliński - mimo skoncentrowania się na działalności politycznej i naukowej - nie zapomniał uwzględnić wątków osobistych w życiu Władysława Konopczyńskiego. Przykładowo - w tak istotnym okresie jego życia, jakim był konflikt z Szymonem Askenazym - uczony zerwał zaręczyny z Marią Jarosiewiczówną, a następnie poślubił Jadwigę Lutostańską. Podobnych wątków z życia profesora i jego rodziny znajdujemy więcej w omawianej biografii. W efekcie Władysław Konopczyński jawi się nie tylko jako 
uczony i polityk, ale też jako człowiek zmagający się z codziennymi problemami, szukający ukojenia w odziedziczonym po ojcu niewielkim majątku ziemskim Młynik pod Ojcowem.

\author{
Mateusz Hübner \\ (Uniwersytet Mikołaja Kopernika w Toruniu) \\ https://orcid.org/0000-0003-0438-4315
}

\title{
BIBLIOGRAFIA (REFERENCES)
}

Biliński P., Lwowskie lata Władysława Konopczyńskiego, „Wrocławskie Studia Wschodnie” 2014, 18.

Biliński P., Polemika Władysława Konopczyńskiego z Mieczysławem Skibińskim, „Studia z Historii Społeczno-Gospodarczej XIX i XX wieku", t. 14, red. J. Kita, 2015.

Biliński P., Spór Władysława Konopczyńskiego z Szymonem Askenazym, w: Władysław Konopczyński jako badacz dziejów XVIII wieku, red. Z. Zielińska, W. Kriegseisen, Warszawa 2014.

Biliński P., Stanistaw Kutrzeba (1876-1946). Biografia naukowa i polityczna, Kraków 2011.

Biliński P., Władysław Konopczyński. Historyk i polityk II Rzeczypospolitej (1880-1952), Warszawa 1999.

Biliński P., Władysław Konopczyński 1880-1952. Człowiek i dzieło, Kraków 2017.

Folkierski W., Tytan historycznej pracy. Władysław Konopczyński, „Myśl Polska” 15 VIII 1952.

Konopczyński W., Dzieje Polski nowożytnej, t. 1-2, Warszawa 1936.

Konopczyński W., Dziennik 1918-1921, cz. 1-2, oprac. P. Biliński, P. Plichta, WarszawaKraków 2016.

Konopczyński W., Józef Szujski 1835-1883, Warszawa 1993.

Konopczyński W., Konfederacja barska, t. 1-2, Warszawa 1936-1938.

Konopczyński W., Liberum veto. Studyum porównawczo-historyczne, Kraków 1918. 